\title{
Copepod Distribution in Relation to Seasonal Hydrographics and Spatial Structure in the North-western Mediterranean (Golfe du Lion)
}

\author{
Juliana H. M. Kouwenberg \\ Institute of Taxonomic Zoology, University of Amsterdam, P.O. Box 4766, \\ 1009 AT Amsterdam, The Netherlands
}

Received 19 May 1992 and in revised form 22 March 1993

\begin{abstract}
Keywords: copepod distribution; seasonal changes; north-western Mediterranean

Copepod abundance and hydrography from the upper $50 \mathrm{~m}$ in the Golfe du Lion (NW Mediterranean) were studied during 1986-88. Seasonal distributions of eight genera and 35 species at 87 stations were analysed by means of numerical classification. An obvious distinction can be observed between near-coastal/ neritic stations and oceanic stations. Most abundant copepods were epipelagic and non-migrating like: Clausocalanidae, Oithonidae, Paracalanus parvus, Oncaeidae, Centropages typicus and Temora stylifera. Inverse analysis demonstrated (1) High densities for the epipelagic, non-migrating Clausocalanidae and Oithonidae over many clustered station groups. Paracalanus parvus and $C$. typicus were abundant during the summer sampling periods whereas $T$. stylifera was abundant in September. Common were some vertical migrators like: Calanus helgolandicus, Pleuromamma gracilis, Candacia armata and Euchaeta marina. (2) Rare, bathypelagic species were collected during the February and July sampling periods in the upper $50 \mathrm{~m}$. In February this synchronized with vertical mixing of the water column, in July with locally upwelled deep intermediate water, remaining below the thermocline. Relatively high mean subsurface temperatures were measured in December and February. Salinities showed a considerable variation in Rhône influence between the different seasons. Species with mainly herbivorous feeding habits were more abundant than those of more diverse omnivorous or carnivorous feeding habits.
\end{abstract}

\section{Introduction}

The Golfe du Lion in the north-western Mediterranean has distinct hydrographical and geological characteristics. The wide continental shelf (down to $200 \mathrm{~m}$ depth) changes rapidly into an oceanic part with more than $2000 \mathrm{~m}$ depth. The waters in this basin originate from: $(1)$ the Atlantic ( $\approx 50 \mathrm{~m}$ depth). This water is considerably modified after entering the Strait of Gibraltar (Millot, 1987), but is still influenced by the Atlantic, since species characteristic for Atlantic waters occasionally show up (Gaudy, 1963, 1985; Mazza, 1967; Estrada et al., 1985); (2) the eastern Mediterranean ( $\approx 200-400 \mathrm{~m}$ depth); 


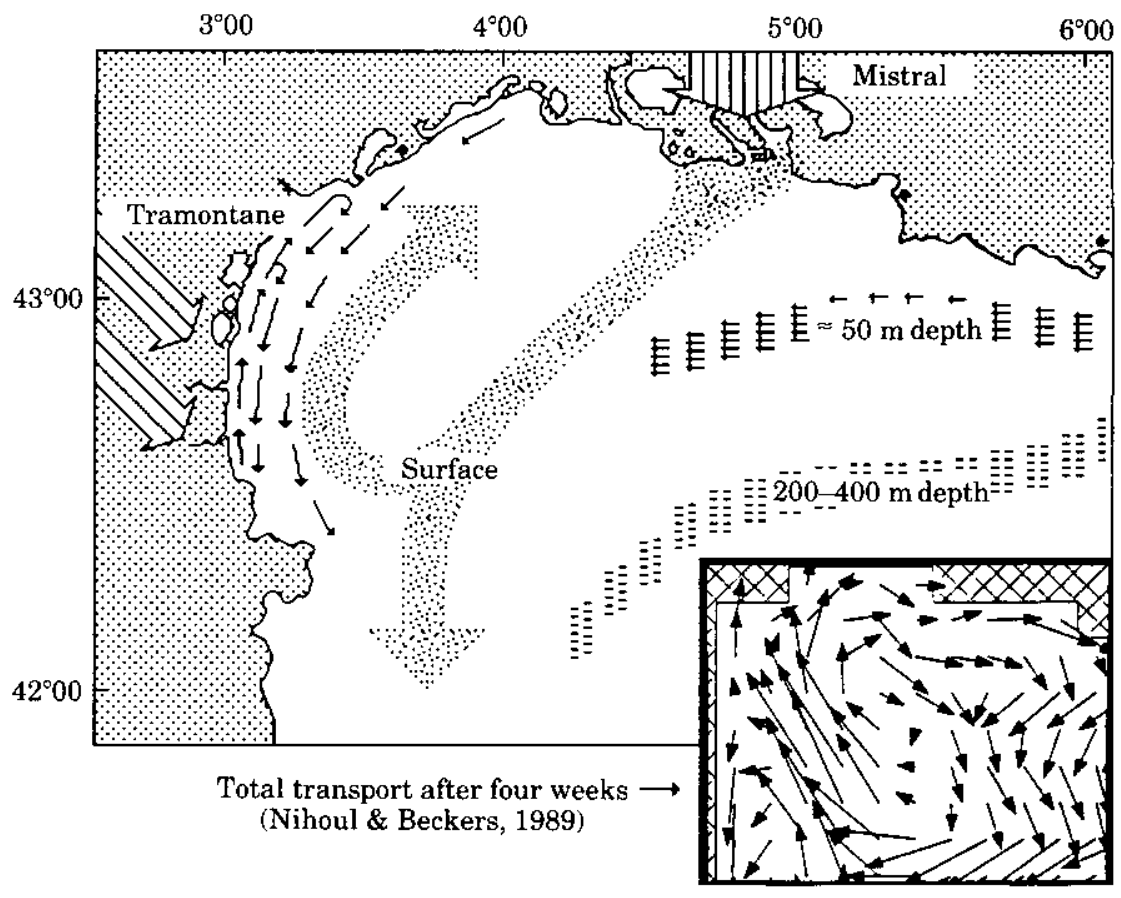

Figure 1. Schematic presentation of some current patterns, surface transport and coastal processes with Rhône influence and dominating wind-regimes in the Golfe du Lion. $\rightleftarrows$, Assumed circulation during Tramontane (Millot, 1976); 㭋, strongly mixed and modified water of Atlantic origin (Furnestin \& Allain, 1962); Mediterranean water (Furnestin \& Allain, 1962); Allain, 1962).

and (3) the River Rhône. A thin layer of fresh, nutrient-rich Rhône water (plume) covers the saline water. The surface waters mix in a cyclonic current pattern (Figure 1) as described by Furnestin and Allain (1962), Millot (1976), Nihoul and Beckers (1989), Nihoul et al. (1990), Salat et al. (1990) and Brasseur (1992). Mean surface salinities range from 33 in the Rhône delta up to 38.2 in the south-eastern part of the gulf (Furnestin, 1960; Brasseur, 1992). Two wind-regimes, the northern 'Mistral' (Rhône valley) and the north-western 'Tramontane' dominate water movements. They strongly influence coastal upwellings, mixing of fresh and saline water (Cruzado \& Velasquez, 1990), and surface current directions (Millot, 1979, 1981).

Zooplankton distribution is closely related to the (seasonal) changes in hydrodynamic features and circulation patterns. Copepods are important contributors to zooplankton biomass in the Golfe du Lion (Razouls, C., 1972) and extensive research has been done on the copepod fauna during the last 30 years (Furnestin, M.L., 1960, 1979; Vives, 1963; Thiriot, 1965; Mazza, 1966, 1967; Gaudy, 1970, 1971; Razouls, C., 1972, 1973; Estrada et al., 1985; Kouwenberg \& Razouls, 1990; Kouwenberg, 1993a). Most common copepods in the Mediterranean are cosmopolitan; many have an Atlantic, and some an Indo-Pacific origin. Less common species are of Boreo-Arctic and tropical origin (Vervoort, 1946, 1963, 1965; Sewell, 1948; Mazza, 1967). Copepod species diversity in the Mediterranean 
is considerable with 469 species (Razouls \& Durand, 1991); 186 species occur in the Golfe du Lion, but only 25 are important in secondary production (Furnestin, 1979).

The biology and ecology of individual copepod species from the Golfe du Lion were studied by Gaudy (1970, 1972), Razouls, C. (1972), Razouls, S. (1972), Razouls and Guinness (1973), and Razouls and Razouls (1976), but little attention has been given to the distribution of copepod assemblages in relation to seasonal and hydrodynamical characteristics.

In this paper only the copepods from the upper $50 \mathrm{~m}$ layer and at shallower depth $(\approx 20 \mathrm{~m})$ at the near-coastal stations are considered. This represents the subsurface and euphotic upper layer in most seasons and facilitates comparison of near-coastal, neritic and oceanic stations. In addition, hydrographical and climatic effects, characteristic for the region, are most pronounced at these shallower depths.

\section{Material and methods}

Zooplankton samples were collected with a triple-WP2 vertical sampling net (Unesco, 1968), of mesh size $200 \mu \mathrm{m}$, in the near-coastal, neritic and oceanic region in the Golfe du Lion during five cruises of the multidisciplinary French/Spanish Pélagolion and Leopel programmes. Depth permitting, a total of 87 stations were alternately sampled by day and by night in vertical hauls at different depths. This paper is based on the $50-0 \mathrm{~m}$ samples. The five cruises (Figure 2) provided a good degree of seasonal coverage. At every station CTD data (bottom depth, salinity, temperature) were recorded. Geographical position, wind speed, cloud cover, time and date were noted. On board ship the sampled zooplankton was preserved in $4 \%$ neutralized formaldehyde.

After subsampling with a planktonsplitter (Razouls, C., 1972), about one thousand copepods per sample were identified and counted under a stereo-microscope. Most copepods were identified to species level (Rose, 1933), except for the Clausocalanidae, Oithonidae, Oncaeidae and Corycaeidae which were identified to genus level. According to Furnestin, M.L. (1960) Clausocalanus arcuicornis Dana, 1849 and C. furcatus Brady, 1883, occur abundantly in the Golfe du Lion, C. arcuicornis being the most abundant. Among Oithona, the most abundant species are $O$. nana Giesbrecht, 1892 and $O$. helgolandica Claus, 1863. The most important species in Oncaea are O. media Giesbrecht, 1891 and $O$. venusta Philippi, 1843. Eleven species represent the Corycaeidae (Razouls, 1973), the most common being Corycaeus ovalis Claus, 1863 and Farranula rostrata (Claus, 1863). The number and relative abundance of species and genera were calculated per $\mathrm{m}^{2}$ for each station in every season.

A difference in copepod densities between day and night was expected due to the diurnal vertical migration of some species. A one-way analysis of variance was applied, testing the null hypothesis that both samples come from the same population and therefore have the same means and variances $\left(\mu_{1}=\mu_{1}^{2} ; \sigma_{1}{ }^{2}=\sigma_{2}^{2}\right)$. The difference in day and night sample means was not significant at the $5 \%$ level, so $H_{0}$ was not rejected. Therefore the day and night samples were pooled.

In order to classify the samples, the collected data were analysed by means of numerical classification. The data for all 87 sampling stations, comprising the abundance of 35 species and eight genera were combined into one large data table and analysed by cluster analysis. The average linkage method (Sokal \& Mitchener, 1958) combined with the Bray-Curtis dissimilarity coefficient was chosen for clustering (Longhurst, 1985; Kaandorp, 1986; de Kluijver, 1989; Gowing \& Garrison, 1991). This approach has the 


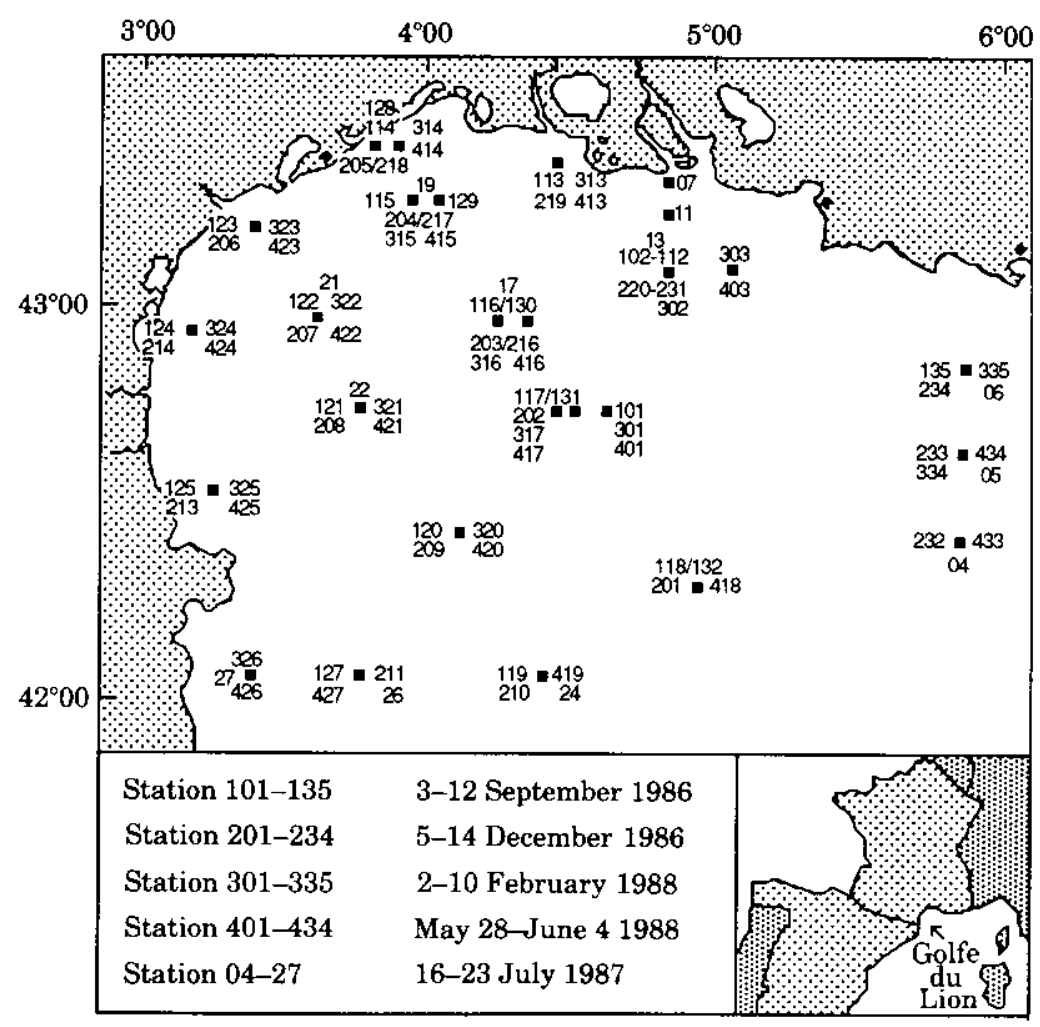

Figure 2. Location of sampling stations over the period 1986-88.

advantage of integrating sample results and species results. Field et al. (1982) formulated the Bray-Curtis equation as:

$$
\partial_{j k}=\frac{\sum_{i=1}^{s}\left|Y_{i j}-Y_{i k}\right|}{\sum_{i=1}^{s}\left(Y_{i j}+Y_{i k}\right)}
$$

where $Y_{i j}$ is the number of the $i$ th species in the $j$ th sample; $Y_{i k}$ is the number of the $i$ th species in the $k$ th sample; $\partial_{j k}$ ranges from 0 (identical scores for all species) to 1 (no species in common). A logarithmic transformation of the data set was chosen in order to give less weight to the dominant species and to give more weight to qualitative aspects of the data (van Tongeren, 1987).

$$
\begin{array}{cc}
x=0 \cdot 0 & T(x)=0 \\
10 \leqslant x \leqslant 100 \cdot 000 & T(x)=\log (0 \cdot 1 x+1)
\end{array}
$$

in which $x$ is the number of individuals $\mathrm{m}^{-2}$ and $T(x)$ the corresponding transformed value. Using the $\log$ transformation it is necessary that the minimal value of presence (which is not 0 ) is transformed to 1 . The lowest value from this data set was 10 copepods $\mathrm{m}^{-2}$. In order to transform this to 1 , all values were converted to $0 \cdot 1 x$. The use of $\log$ $(0 \cdot 1 x)+1$ was necessary because the minimum values were as low as 10 copepods $\mathrm{m}^{-2}$. 
After classification of all samples (the normal cluster analysis), a classification of the species in an inverse analysis was performed using the program SRTORD (Kaandorp, 1986). This inverse analysis reveals the species abundance and combinations, responsible for the separation of the different clusters. Species groups were identified using the 'variable stopping rule' which is based on the perception that individual groups with relative internal homogeneity may cluster at different levels of resemblance (Boesch, 1977). Stations with a low species diversity do always cluster at a lower similarity level with the group having the same dominant species and characteristics. Using the "fixed stopping rule' these stations would be isolated, but now they join the station group with the same species dominance. The inverse analysis will show which species are responsible for clustering of a station at a lower similarity level. The data set includes both common and rare species. It seems reasonable to require higher intra-group resemblance in groups of common species than in groups of rare species for which the probability of co-occurrence is low. In data interpretation, however, attention is also paid to the value of the rare species.

\section{Results}

All species and genera collected during the sampling periods are listed in Table 1 in order of ubiquity together with a classification of main feeding strategies (mainly herbivorous, carnivorous, omnivorous).

\section{Cluster analysis}

The dendrogram resulting from the cluster analysis of all data (Figure 3) shows the dissimilarity of the stations based on the quantities of the different copepod species. In Figure 4 the clustered station groups are geographically presented. The stations, grouped in the sub-clusters A1-A5 overlap mainly the September, December and July sampling periods. The stations, grouped in the sub-clusters B1-B4 were sampled during February (B1-B2) and May/June (B3-B4). The stations, grouped in the clusters, C, D and E were sampled during the summer, and those grouped in the $\mathrm{F}$ cluster were sampled during December.

\section{Inverse analysis}

Table 2 shows the distribution of species over all clustered station groups. Some species are common, others are restricted to one or a few (sub)clusters at a concentration level of $90 \%$.

Sub-cluster characteristics based on species abundance and diversity. The vertical structure in the inverse analysis (Table 2) shows that the station groups (clusters and sub-clusters in A-F) can be distinguished by a number of characteristics.

Sub-cluster A1 (Rhône-plume environment in September and December, Figure 4) is characterized by highly dominating Clausocalanus spp., with the highest mean abundance of all clusters and sub-clusters $\left(36.5 \times 1000 \mathrm{~m}^{-2}\right)$. Other important species in this subcluster are Oithona spp. and Temora stylifera. Well represented, but not so abundant are Centropages typicus, Oncaea spp. and Pleuromammagracilis.

Sub-cluster A2 (neritic, outside the Rhône plume in December and February, Figure 4) is also dominated by Clausocalanus spp. and secondly by Oithona spp. but mean numbers 
Table 1. All species and genera collected during the different sampling periods in the upper $50 \mathrm{~m}$ with main feeding strategies. Sources: Wickstead $(1959,1962)$, Corner (1961), Anraku and Omori (1963), Arashkevich and Timonin (1970), Nassogne (1970), Timonin (1971), Harding (1974), Bennet and Hopkins (1989)

Species/genera

Abundant and frequent

Clausocalanus spp.

Oithona spp.

Paracalanus parvus (Claus, 1863)

Oncaea spp.

Centropages typicus Krøyer, 1849

Temora stylifera (Dana, 1849)

Calanus helgolandicus (Claus, 1863)

Corycaeus spp.

Acartia clausi Giesbrecht, 1889

Ctenocalanus vanus Giesbrecht, 1888

Pleuromammagracilis (Claus, 1863)

Calocalanus spp.

Candacia armata (Boeck, 1872)

Frequent, not abundant

Euterpina acutifrons (Dana, 1847)

Euchaeta marina (Prestandrea, 1833)

Neocalanus tenuicornis Dana, 1847

Heterorhabdus papilliger (Claus, 1863)

Clytemnestra rostrata (Brady, 1883)

Nannocalanus minor (Claus, 1863)

Neocalanus gracilis (Dana, 1849)

Macrosetella gracilis (Dana, 1848)

Microsetella spp.

Rare, moderate in summer

Eucalanus elongatus (Dana, 1849)

Euchirella rostrata (Claus, 1866)

Sapphirina spp.

Monacilla typica Sars, 1905

Rare

Oithona plumifera Baird, 1843

Haloptilus spp.

Centropages violaceus (Claus, 1863)

Lucicutia flavicornis (Claus, 1863)

Aetideopsis rostrata Sars, 1903

Aetideus armatus (Boeck, 1872)

Anomalocera patersonii Templeton, 1837

Candacia simplex Giesbrecht, 1889

Isias clavipes Boeck, 1864

Pleuromamma abdominalis (Lubbock, 1856)

Heterorhabdus spinifrons (Claus, 1863)

Mecynocera clausi 1. C. Thompson, 1888

Parapontella brevicornis (Lubbock, 1857)

Euchaeta acuta Giesbrecht, 1892

Oncaea conifera Giesbrecht, 1891

Scolecithricella dentata (Giesbrecht, 1892)

Mormonilla phasma Giesbrecht, 1891
Main feeding strategy

Herbivorous (fine filter-feeders)

Carnivorous (piercing and sucking)

Herbivorous (fine filter-feeders)

Carnivorous (piercing and sucking)

Omnivorous

Herbivorous

Herbivorous

Carnivorous (piercing and sucking)

Omnivorous

Herbivorous

Omnivorous, carnivorous

Herbivorous (fine filter-feeders)

Carnivorous (piercing and sucking)

Herbivorous

Carnivorous (seizing and masticating)

Herbivorous

Carnivorous (piercing and sucking)

Herbivorous

Herbivorous (fine filter-feeders)

Herbivorous (coarse filter-feeders)

Herbivorous

Herbivorous

Herbivorous (coarse filter-feeders)

Omnivorous

Carnivorous

Carnivorous

Carnivorous (piercing and sucking)

Carnivorous (piercing and sucking)

Omnivorous

Herbivorous (coarse filter-feeders)

Carnivorous

Carnivorous

Carnivorous

Carnivorous (piercing and sucking)

Omnivorous

Ominivorous

Carnivorous (piercing and sucking)

Herbivorous

Carnivorous

Carnivorous (seizing and masticating)

Carnivorous (piercing and sucking)

Omnivorous

Herbivorous

are lower per $\mathrm{m}^{2}$. This is also true for T. stylifera and C. typicus, whereas mean Oncaea spp. numbers remain about the same. On the other hand, Corycaeus spp. shows its maximum abundance in this sub-cluster with mean numbers of $2.5 \times 1000 \mathrm{~m}^{-2}$.

In sub-cluster A3 (coastal and oceanic stations in September, coastal in December, Figure 4) a sharp decline can be observed in the still dominating Clausocalanidae and 


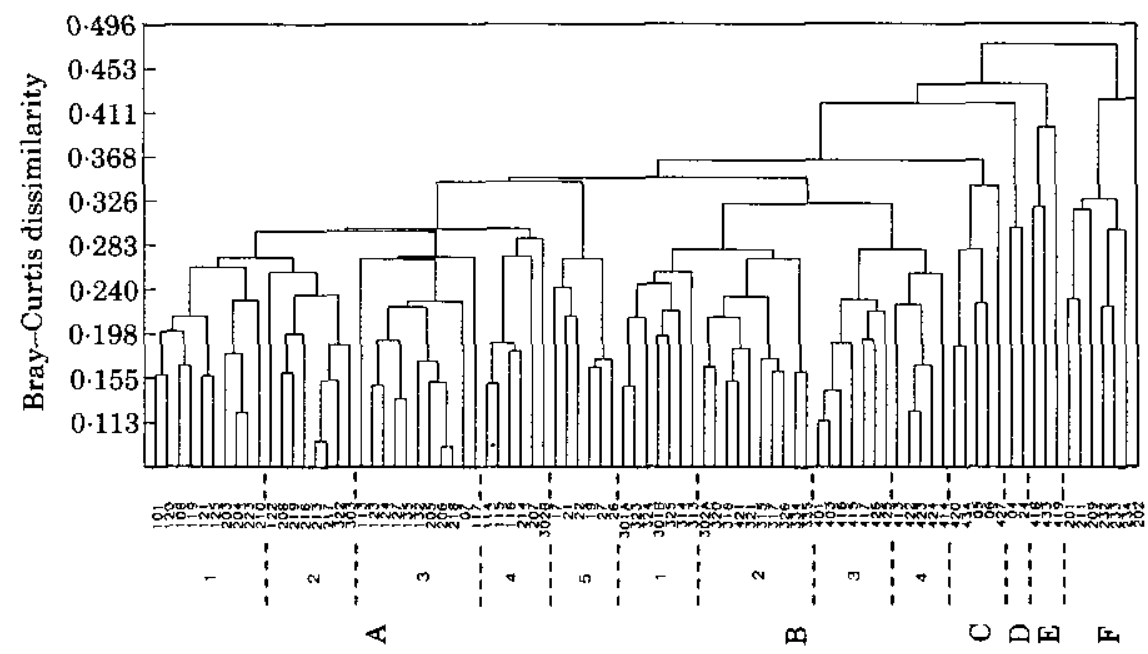

Figure 3. Dendogram showing classification of 87 stations, comprising all combined data. The distinguished clusters are marked with letters (A-F), the sub-clusters with A1-A5 and B1-B4.

Oithonidae to less than half the mean numbers $\mathrm{m}^{-2}$ of sub-cluster $\mathrm{A} 1$. Mean numbers of C. typicus and T. stylifera are somewhat higher than in sub-cluster A2, but lower than in sub-cluster Al.

Sub-cluster A4 (neritic and coastal stations, north-west of the Rhône plume in September and December, Figure 4) is characterized by: (a) higher quantities of Acartia clausi, Calanus helgolandicus and Paracalanus parvus, which were of low importance in sub-clusters A1-A3; (b) species diversity is higher (20) in comparison with sub-cluster A3 (13); (c) Clausocalanus spp., Oncaea spp. and Oithona spp. dominate and (d) C. typicus and T. stylifera show maximum mean values of all A sub-clusters.

Sub-cluster A5 (neritic stations in July, Figure 4) is characterized by a highly dominating $P$. parvus with a mean abundance of $33.3 \times 1000 \mathrm{~m}^{-2}$ over this station group. It is the only sub-cluster in which $P$. parvus shows these high abundances. Mean numbers of Clausocalanus spp. are much reduced $\left(15.6 \times 1000 \mathrm{~m}^{-2}\right)$. Oithonidae, Oncaeidae and $C$. helgolandicus show the maximum values of all clusters. Vertical migrators, like Euchaeta marina and Neocalanus gracilis are present. Furthermore, some rare species, like Aetideus armatus, Aetideopsis rostrata, Eucalanus elongatus, Sapphirina spp. and Anomalocera patersonii concentrate in this sub-cluster.

Sub-cluster B1 (near-coastal stations in February, Figure 4) shows very low mean values of all important species. Clausocalanus spp. and Oithona spp. dominate with 4.9 and $1.8 \times 1000 \mathrm{~m}^{-2}$, respectively.

In sub-cluster B2 (neritic and oceanic stations in February, Figure 4) Clausocalanus spp. and Oithona spp. dominate with considerably higher mean values than in sub-cluster Bl. Calanus helgolandicus shows relatively high values in comparison with the other clusters. Rare species, like Lucicutia flavicornis, Monacilla typica, Aetideopsis rostrata, Neocalanus gracilis, Aetideus armatus, Isias clavipes, Mecynocera clausi, Candacia simplex and Parapontella brevicornis were concentrated here, as was also observed in sub-cluster A5.

Sub-cluster B3 (neritic stations near Rhône plume and south-west in May/June, Figure 4 ) is characterized by dominating $P$. parvus and Oithona spp. with low mean values for the Clausocalanidae. It is the only sub-cluster in which Nannocalanus minor is of some 

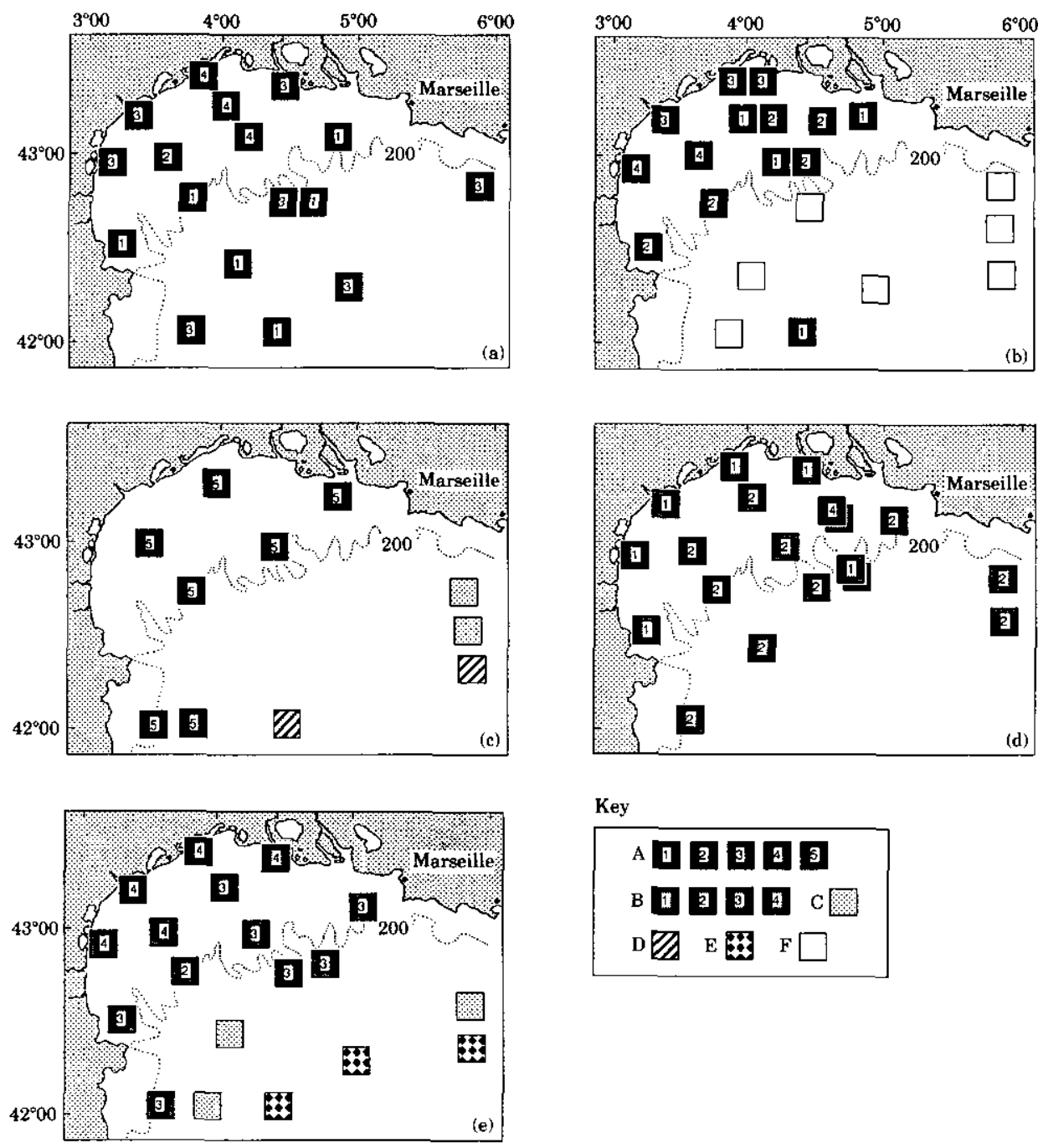

Key

A $19 \mathbf{3} \mathbf{3}$

в 1090 $\mathrm{C}$ 圆

$\mathrm{D}$ E

Figure 4. Geographical location of the by cluster analysis grouped stations. (a) September 1986, (b) December 1986, (c) July 1987, (d) February 1988, and (e) May/ June 1988.

importance; Ctenocalanus vanus has its maximum mean values here with $1.8 \times 1000 \mathrm{~m}^{-2}$.

In sub-cluster B4 (near coastal-stations in May/June, Figure 4) the generally dominant Clausocalanidae show their minimum values. The Oithonidae dominate and $P$. parvus is second in abundance. Species diversity is very low.

Cluster C (oceanic stations in June/July, Figure 4) shows high dominance of Clausocalanus spp. and Oithona spp. Maximum mean values were measured here for C. typicus $\left(6.5 \times 1000 \mathrm{~m}^{-2}\right)$, Oithona spp. $\left(12.0 \times 1000 \mathrm{~m}^{-2}\right)$ and Pleuromamma gracilis $\left(1.6 \times 1000 \mathrm{~m}^{-2}\right)$. Two rarely encountered species in the upper $50 \mathrm{~m}$ are restricted to this cluster, namely Oncaea conifera and Euchirella rostrata.

Cluster D (oceanic stations in July, Figure 4) comprises only two stations, showing low species diversity and low mean values for the otherwise abundant species. Clausocalanus spp. dominate slightly; other species, even Oithona spp. are of minor importance. 
Cluster E (oceanic stations in June, Figure 4) comprises three stations. Here again low species diversity occurs, but Clausocalanus spp. dominates with much higher mean values than in cluster D. Higher values are also apparent for C. typicus and Oithona spp.

Finally in cluster F (oceanic stations in December, Figure 4) only the Clausocalanidae are of some importance; other species show very low values or are absent.

Copepod assemblages. Horizontally, 15 different assemblages can be distinguished in Table 2. (1) Species that occurred most clustered at station groups from A to F. However, except for the Clausocalanidae, which were present at all station groups, all other species in this assemblage were absent in clusters $\mathrm{D}$ and $\mathrm{E}$, representing the oceanic stations in early and mid-summer. Euchaeta marina, Neocalanus gracilis and Lucicutia flavicornis were never found at near-coastal stations, grouped in sub-clusters B1 (February) and B4 (May/June). (2) Two rare species, Scolicithricella dentata and Mormonilla phasma were restricted to cluster F, representing the oceanic region in December. (3) The species that were for $90 \%$ spread over the clusters $\mathrm{A}$ to $\mathrm{E}$, and not in cluster $\mathrm{F}$. The most frequent and abundant species here were C. typicus, Acartia clausi and Oithona spp. (4) Microsetella spp., occurring rather frequently but very low in numbers, was the only species, spread over the stations, grouped in clusters A to D. (5) A large assemblage was spread over clusters A to $\mathrm{C}$, thus restricted to the coastal and neritic region, with the most important species being: C. helgolandicus, C. vanus, $P$. gracilis and Candacia armata. (6) Oncaea conifera and Euchirella rostrata were restricted to the stations, grouped in cluster C. (7) The most important species spread for $90 \%$ over the stations, grouped in clusters A to B were $P$. parvus, Oncaea spp., Euterpina acutifrons and Corycaeus spp. (8-15) Temora stylifera is the only important species which was restricted for $90 \%$ to the stations grouped in the subclusters A1-A4, the other assemblages consist of rarely encountered species which were restricted to sub-clusters from the $A$ and $B$ clusters.

\section{Salinities and temperatures}

Surface salinities and salinities at $50 \mathrm{~m}$ depth are presented in Figure 5(a,b). Rhône river outflow results in a considerable influence zone at the surface during September, December and May/June. In February this influence was less pronounced. During May/ June variability in surface salinities was highest; during September lowest. At $50 \mathrm{~m}$ depth salinities were higher and less variable during each season. During December, February and May/June bottom salinities were lower at the near-coastal stations ( $\pm 20 \mathrm{~m}$ depth) than at the neritic and oceanic stations at $20 \mathrm{~m}$ (Table 3 ) and $50 \mathrm{~m}$. Table 3 shows the mean salinities and temperatures for the stations, grouped by cluster analysis at three different depths; surface, $20 \mathrm{~m}$ depth and $50 \mathrm{~m}$ depth. Between the different clusters there are no significant differences in salinities or temperatures, except for the stations grouped in cluster D (July).

\section{Discussion}

The copepod groups showing a similar distribution pattern (Table 2 and Figure 4) are a mixture of surface and subsurface dwellers and strong migrators. The vertical migrators, like Calanus helgolandicus, Pleuromamma gracilis, Candacia armata, Euchaeta marina and Heterorhabdus papilliger are common but not abundant and the epiplanktonic copepods outnumber them greatly. This is why the difference in sample means between day and night is not significant. 


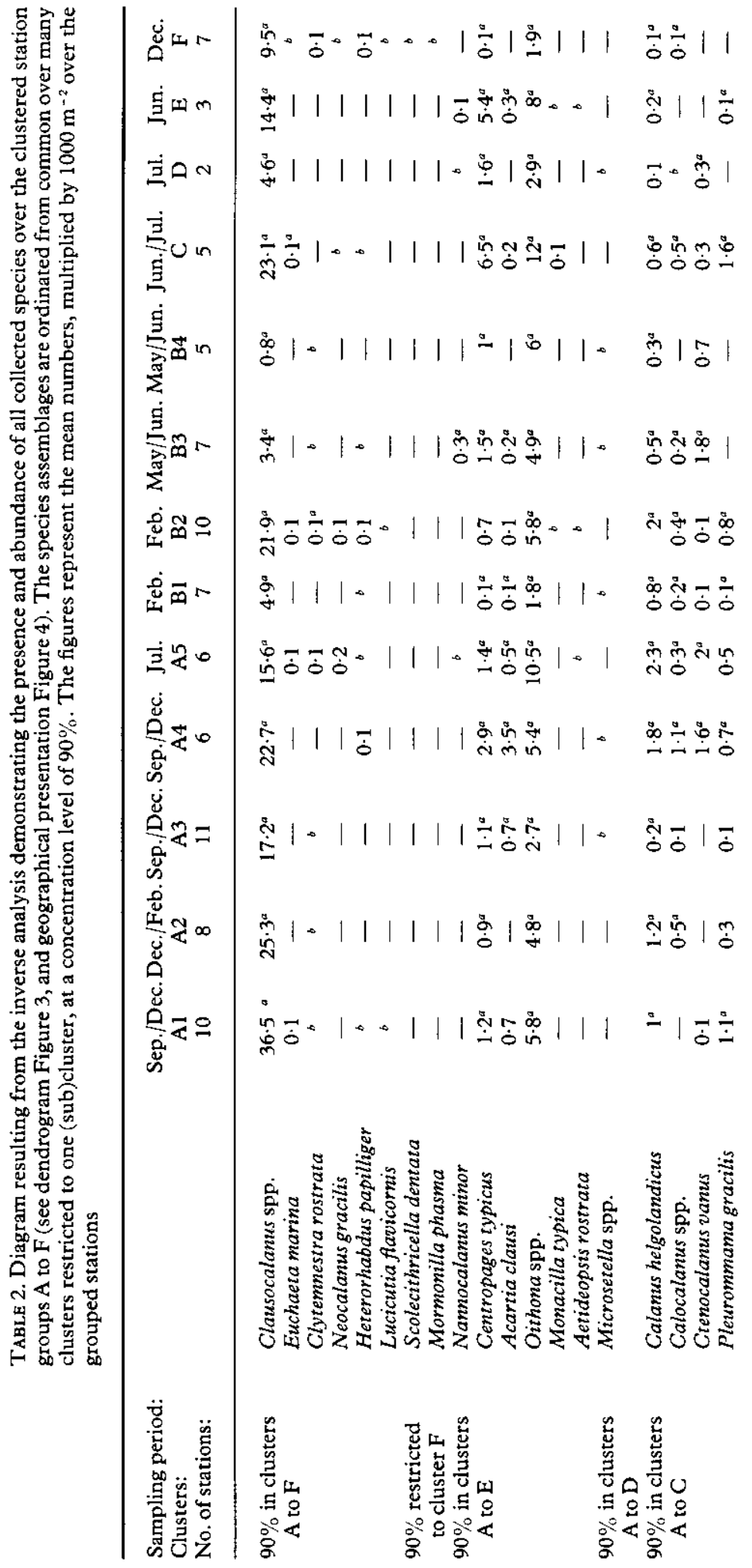




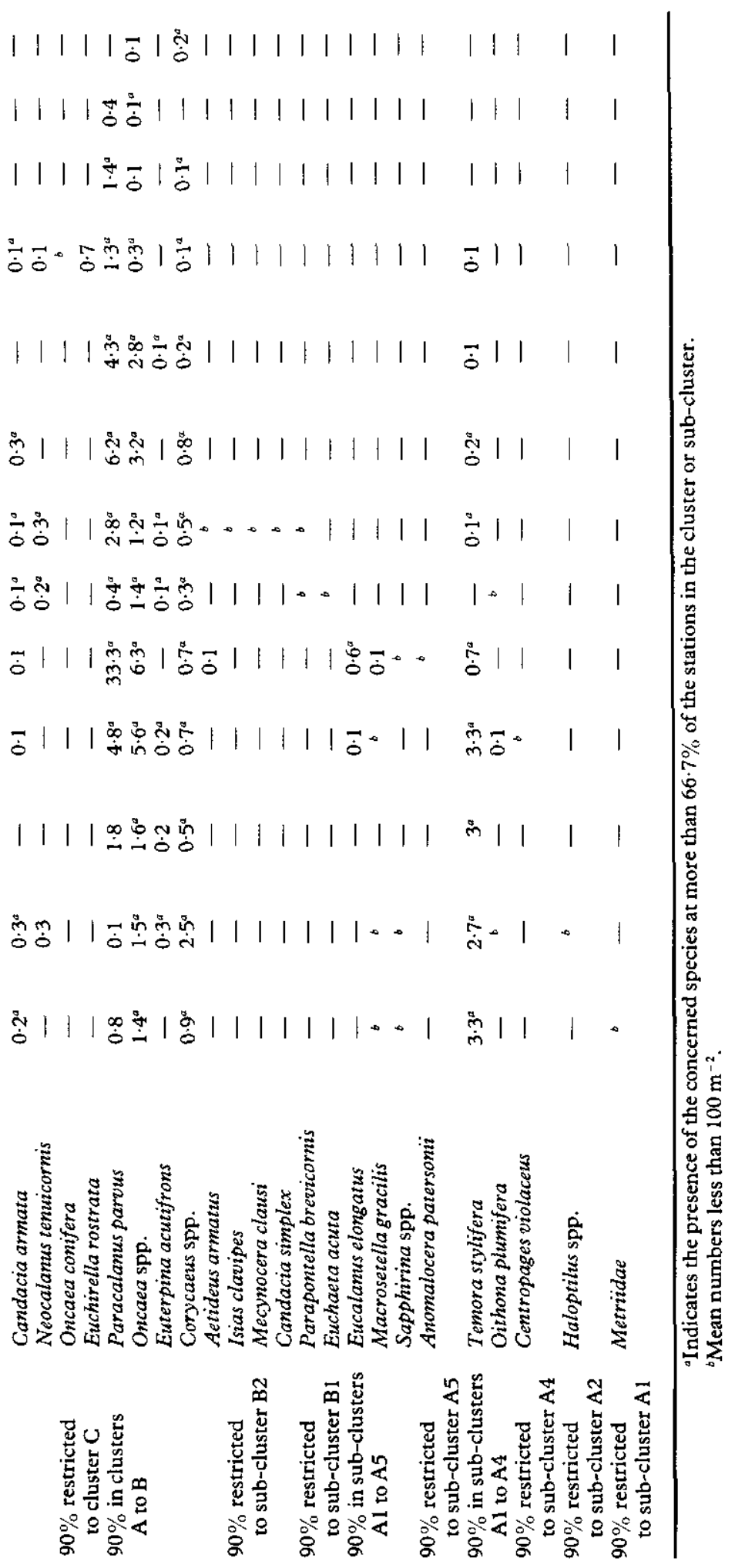



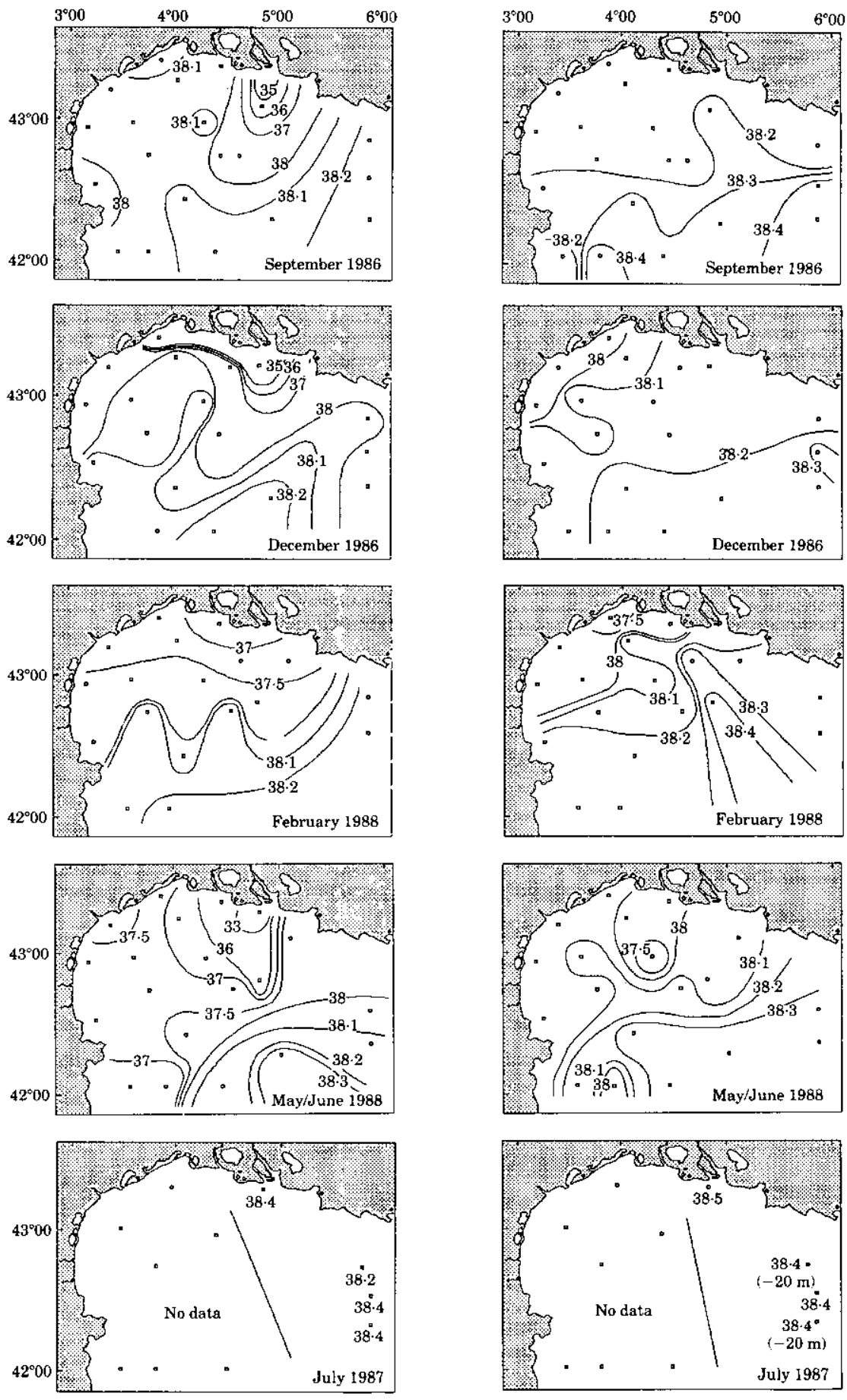

(a)

(b)

Figure 5. (a) Surface salinities in each sampling period and (b) salinities at $50 \mathrm{~m}$ depth and bottom salinities at the shallower $(\approx 20 \mathrm{~m})$ near-coastal stations. 


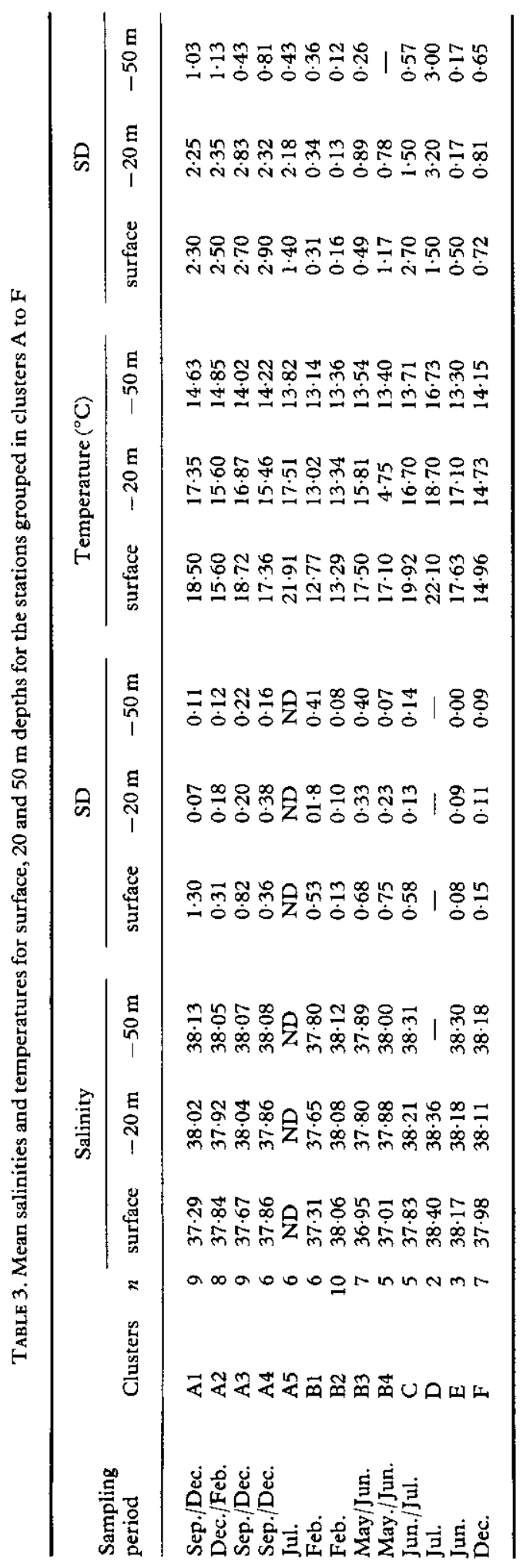




\section{Abundance and distribution pattern in relation to feeding habits}

Many copepods occurring at the stations grouped in the same clusters have different feeding strategies. Wickstead (1962) divided pelagic copepods into three main groups, based on feeding habits: mainly herbivorous forms (selective and random), mixed feeders (true and facultative) and mainly carnivorous forms (selective and random). Studies on the feeding mechanisms of pelagic copepods, which traditionally were called herbivores reveal that many of them are mixed feeders, their diet including a variety of animal food (Anraku \& Omori, 1963; Gaudy, 1974; Poulet, 1978; Paffenhöfer \& Knowles, 1980; Wiadnyana \& Rassoulzadegan, 1989). Daan et al. (1988) observed a tendency for increased predatory behaviour in the absence of other food. In clusters where copepods with mainly herbivorous feeding strategies were abundant, carnivores were also well represented. This confirms the findings of Longhurst (1985), who analysed zooplankton communities in the eastern tropical Pacific Ocean. For example, when the mainly herbivorous Clausocalanidae or Paracalanidae (Frost \& Fleminger, 1968; Timonin, 1971; Paffenhöfer, 1984) were present in high quantities (Table 2), the mainly carnivorous Oithonidae (Lampitt, 1978; Davis, 1984) were also well represented. On the other hand, when the mainly herbivorous forms were low in number, the Oithonidae also showed their minimum abundance. Possibly the Oithonidae feed on the younger stages of Clausocalanus spp. and Paracalanus parvus.

Taking into account that among the most important species in the Golfe du Lion indicated in Table 1, there are two species of mainly herbivorous Clausocalanidae (Clausocalanus arcuicornis and C.furcatus), two species of mainly carnivorous Oithonidae (Oithona helgolandica and O. nana), three species of mainly carnivorous (Wickstead, 1962; Timonin, 1971; Davis, 1984) Corycaeidae (Corycaeus ovalis, C. latus and Corycella rostrata) and two species of mainly carnivorous (Wickstead, 1962; Timonin, 1971; Davis, 1984) Oncaeidae (Onceaea media and O. venusta) (Furnestin, M.L., 1960; Mazza, 1966), it appears that the species diversity of abundant carnivores and omnivores is higher than that encountered among the mainly herbivorous copepods. However, the latter show overall higher abundance (Figure 6). In total, there were 18 mainly herbivorous species and 30 omnivorous carnivorous species (Table 1).

The geographic shape of the sub-clusters A1, A2, A4, A5 and C, representing the station groups where high quantities of the mainly herbivorous copepods Clausocalanus spp. (A1, A2, A4, C) and of Paracalanus parvus (A5) were concentrated is probably more related to the typical areas of seasonally high phytoplankton production, resulting from the high nutrient input by the Rhône River (Cruzada \& Velasquez, 1990) and the seasonal current and wind patterns, revealed on CZCS images (Morel et al., 1990), than to the surface and subsurface salinities at the moment of sampling [see Figure 5(a,b)]. The shapes of the different salinity zones do not correspond at all with the shape of the subclusters. Most epipelagic copepod species in the Golfe du Lion are bound to be euryhaline and eurythermic, because of the high and rapid fluctuations due to climate.

As copepods are able to detect amino acids secreted by phytoplankton cells (Poulet \& Ouellet, 1982) often at long distances (Paffenhöfer, 1991), food conditions may be the most important parameter in the distribution pattern of the mainly herbivorous copepods, which are by far the most abundant in this region, attracting the carnivores which feed on them.

\section{Subsurface winter situation and watermass characteristics}

During December, the Clausocalanidae were the only abundant, mainly herbivorous copepods in the oceanic region. The oceanic stations, grouped in the F cluster are 

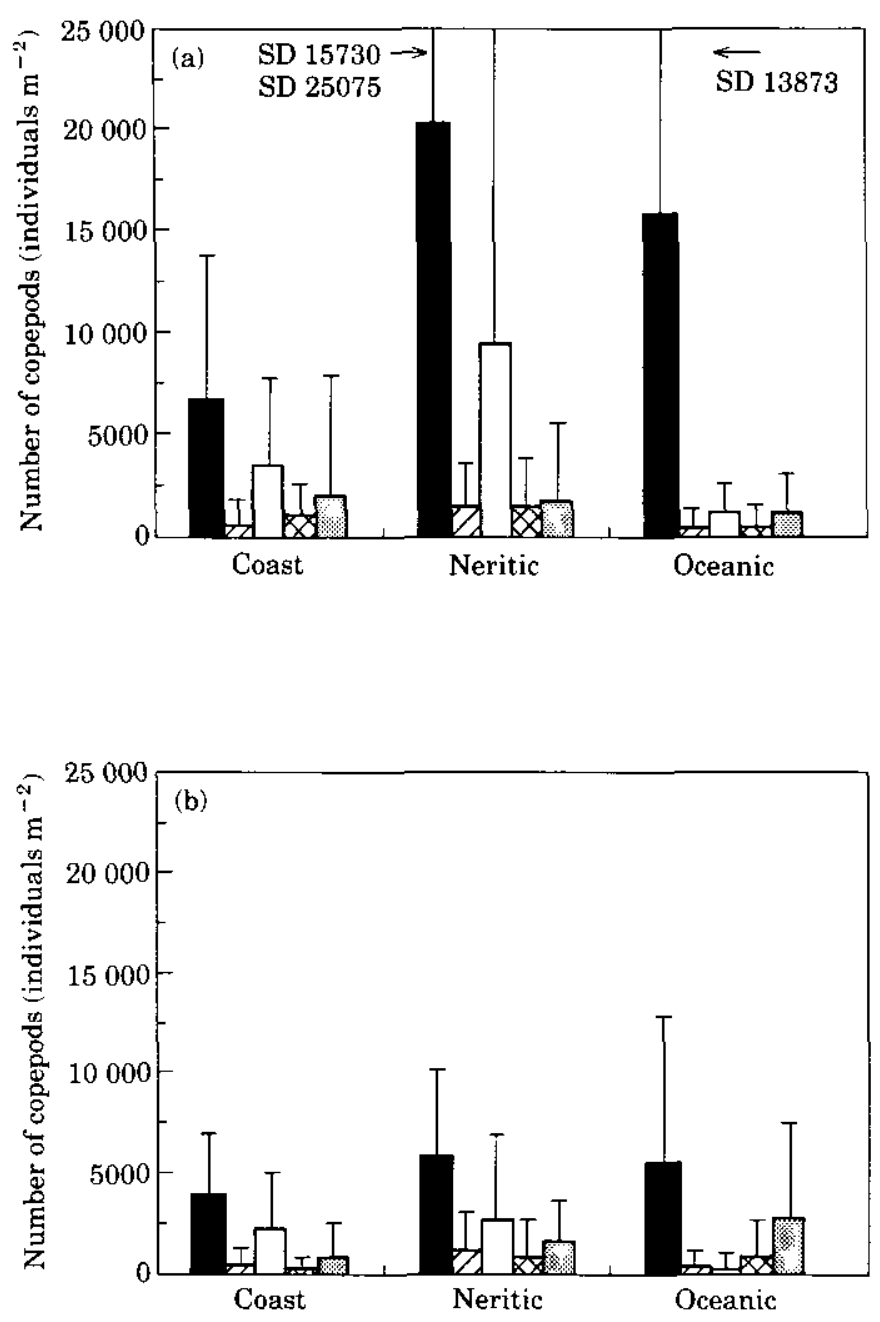

Figure 6. Mean numbers \pm SD of (a) the most abundant mainly herbivorous ( $\boldsymbol{\omega}$, Clauso-

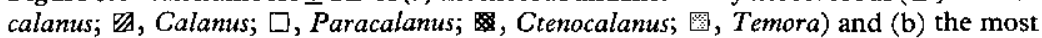

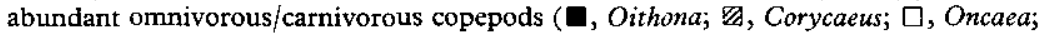
, Pleuromamma; 图, Centropages) in the near-coastal, neritic and oceanic region over all sampled periods.

characterized by low copepod abundance and low species diversity (Figure 7 ). In this period nutrients are exhausted and phytoplankton production is low; mean chlorophyll $a$ values in the oceanic region during the December sampling period for surface, $20 \mathrm{~m}$ depth and $50 \mathrm{~m}$ depth, were $0 \cdot 310,0 \cdot 424$, and $0.225 \mu \mathrm{g} \mathrm{l}^{-1}$ respectively. The Clausocalanidae seem to have the most successful competitive strategy for the remaining food. The other species recorded here are mainly carnivorous, for example Euchaeta marina and Heterorhabdus papilliger (Timonin, 1971).

Compared to previous years, mean water temperatures in December 1986 and February 1988 were relatively high. During the February sampling period in 1988, mean surface temperatures were $12.98^{\circ} \mathrm{C}$ and at $50 \mathrm{~m}$ depth $13.37^{\circ} \mathrm{C}$ (Kouwenberg \& Razouls, 1990). However, mean surface temperatures in February during the years $1965-68$ were $10.62^{\circ} \mathrm{C}$ 


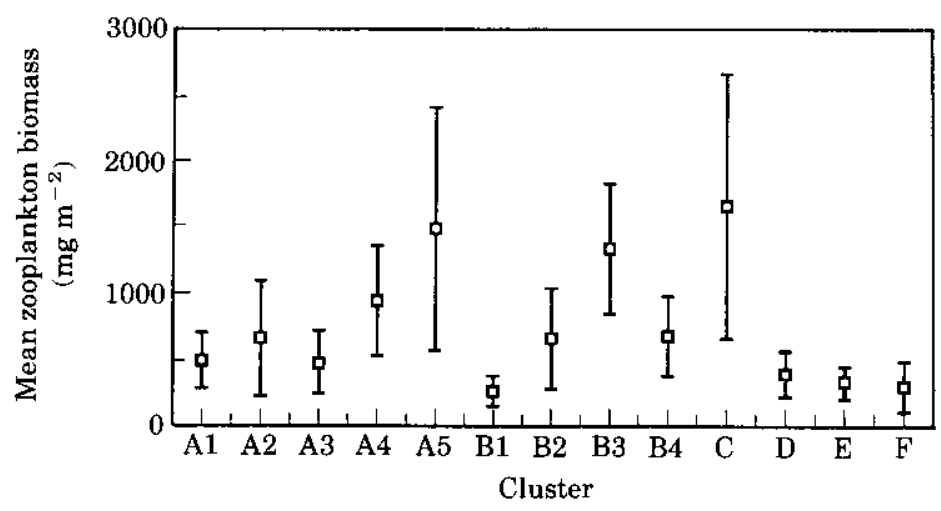

Figure 7. Mean zooplankton biomass from the upper $50 \mathrm{~m} \pm \mathrm{SD}$ for each station group forming the clusters A to F.

(Jacques et al., 1969) and mean temperatures at a depth of $50 \mathrm{~m}$ were $11.87^{\circ} \mathrm{C}$ in February 1969 (Fieux, 1971).

During February, species like Paracalanus parvus, Calanus helgolandicus, and Oithona spp. were more abundant than during December (Kouwenberg, 1993b). Most of the rarely encountered species were concentrated at stations grouped by cluster B2 in February as well (Table 2). They are mesopelagic dor bathypelagic, like Lucicutia flavicornis, Monacilla typica, Aetideopsis rostrata, Aetideus armata, Candacia simplex, Isias clavipes, heterorhabdus spinifrons and Mecynocera clausi (Vervoort, 1963, 1965; Vives, 1963). In February in the neritic area mean salinities and temperatures down to $60 \mathrm{~m}$ depth were similar [Table 2, Figure 8(a)]; mean temperatures remained uniform to a depth of $200 \mathrm{~m}$ $\left(13.29^{\circ} \mathrm{C} \pm 0.15\right.$, unpubl. data). This uniformity is a consequence of frequent vertical mixing movements in January and February, sometimes reaching depths down to $2000 \mathrm{~m}$ (Jacques \& Tréguer, 1986). It results in nutrient transport from deeper layers into the euphotic upper layer. During vertical mixing, a part of the bathypelagic copepod population also appears to rise into the upper $50 \mathrm{~m}$. The nutrient enrichment during vertical mixing is responsible for phytoplankton growth (Jacques et al., 1973). Phytoplankton maxima (and indirectly zooplankton maxima) depend on the importance of the vertical mixing, varying according to the periodicity of cold and mild winters. Margalef (1984) observed that coldest winters preceed high primary production.

\section{Subsurface summer situation and watermass characteristics}

Herbivorous Paracalanus parvus is amongst the most abundant species in the summer period (Table 2). It shows highest numbers in summer at the neritic stations grouped in cluster C2 (>100.000 ind $\mathrm{m}^{-2}$ ). Like the Clausocalanidae with which it successfully competes in summer it is a strongly euryhaline and eurythermic species (Vervoort, 1946).

Not only in February but also in July some meso- and bathypelagic species, like Aetideopsis rostrata, Eucalanus elongatus, Aetideus armatus, Euchirella rostrata, Sapphirina spp. and Oncaea conifera (Vervoort, 1963, 1965) were present in the 50-0 m samples (Table 2 , sub-cluster A5). In summer the surface layer of the neritic and the oceanic region is characterized by nutrient exhaustion. However, during the summer, local and shortlived upwellings induce a phytoplankton-rich layer below the thermocline which occurs at $\approx 30-40 \mathrm{~m}$ depth (Cahet et al., 1972). Thus, the thermocline separates two different watermasses: an oligotrophic surface layer (less than $0 \cdot 1 \mu \mathrm{g}$ chlorophyll $a 1^{-1}$ ) and a 

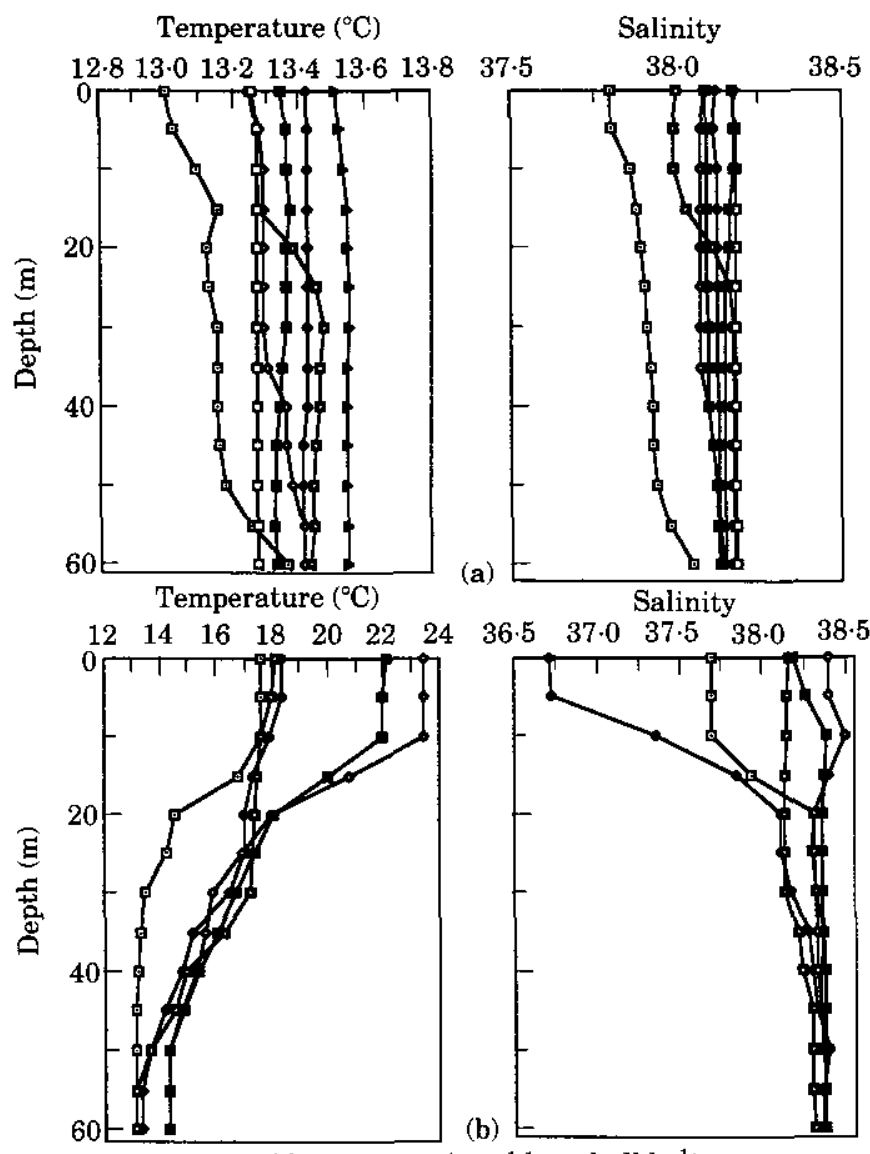

Salinity

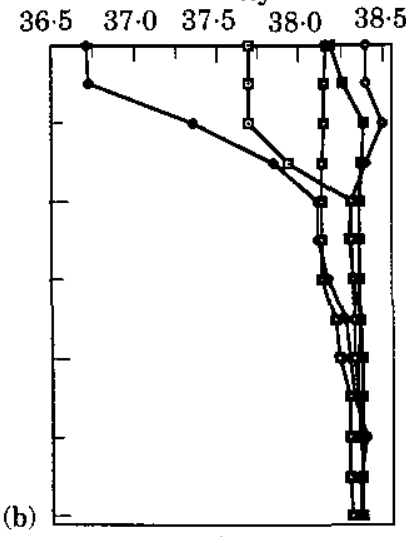

(b)

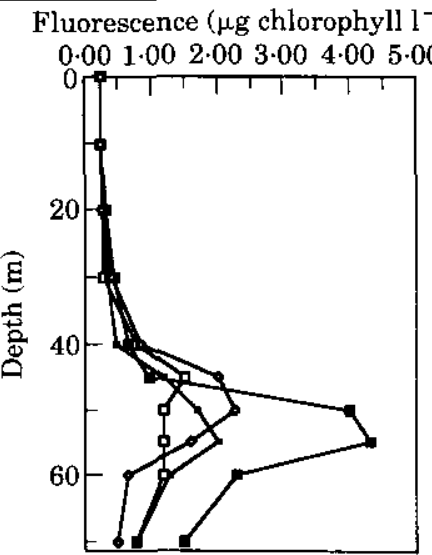

(c)

Figure 8. CTD profiles down to $60 \mathrm{~m}$. (a) The stations grouped in cluster B2 (February) and (b) the stations grouped in cluster C (June/July). (c) Fluorescence profile down to $70 \mathrm{~m}$ of the stations grouped in cluster $\mathrm{E}$ (June 1988).

eutrophic subsurface layer. The summer stations, grouped in sub-cluster A5 (neritic) and cluster $\mathrm{C}$ (oceanic) show a high zooplankton biomass (Figure 7) and the species encountered here probably feed on organisms accumulating at the thermocline, between 
15 and $25 \mathrm{~m}$ depth at most stations [Figure 8(b)]. According to Vives (1963) Centropages typicus, Calanus helgolandicus, Ctenocalanus vanus, and Candacia armata are common winter species that remain under the thermocline in summer. The meso- and bathypelagic species that were found at the stations, grouped by sub-cluster A5 and cluster C (Figure 4) were probably carried along with local upwellings of intermediate waters.

The oceanic summer stations grouped in clusters $\mathrm{D}$ and $\mathrm{E}$ were very poor in zooplankton biomass, at $357 \mathrm{mg} \pm 127 \mathrm{~m}^{-2}$ (Figure 7), and copepod numbers, as well as species diversity, were low (Table 2). The only well-represented species here were Oithona spp., $C$. typicus and $N$. minor. At these stations a fluorescence peak occurred indicating a high chlorophyll content between 50 and $60 \mathrm{~m}$ depth [Figure 8(c)]. Saiz and Alcaraz (1990) found C.typicus maxima at the deep chlorophyll maximum (DCM) at the same depth during the summer stratification period between Barcelona and Mallorca. Probably zooplankton maxima were concentrated in and near this chlorophyll-rich layer and not captured with the $50-0 \mathrm{~m}$ hauls. In support of this, the zooplankton biomass at these stations in the upper $100 \mathrm{~m}$ was much higher, namely $878 \mathrm{mg} \pm 266 \mathrm{~m}^{-2}$.

\section{Indicator species for waters from different origin}

The Rhône River covers the saline subsurface layer with a thin layer of freshwater, not more than the upper 2-10 $\mathrm{m}$ during calm weather conditions (Cruzado \& Velasquez, 1990). Its dilution zone and area of influence strongly depend on the strength of the 'Mistral ' and 'Tramontane', and the direction of other winds. As sampling was done vertically in the upper $50 \mathrm{~m}$, the species composition in the samples of Rhône dilution zone consisted of both euryhaline surface species, tolerating low salinities, and less euryhaline subsurface species. Therefore, species collected by the above-mentioned sampling method cannot be considered indicator species for the freshwater Rhône plume, though indirect influence of the nutrient-rich Rhone outflow can be observed in the high quantities of the mainly herbivorous copepods, feeding in the phytoplankton rich area.

Isias clavipes and Parapontella brevicornis, characteristic for Atlantic influence (Gaudy, 1963,1985 ) were collected incidentally at stations that form clusters B1 and B2 (February), during the period of vertical mixing.

An indicator species of eastern Mediterranean waters, Monacilla typica, (Mazza, 1967) was only found at stations grouped in cluster B2 in February and at stations grouped in clusters $\mathrm{C}$ and $\mathrm{E}$ in the oceanic region in summer. This may indicate that some eastern Mediterranean water $(200-400 \mathrm{~m}$ deep Levantine current) is involved in the vertical mixing process during February, and that in summer the local, short-lived upwellings, responsible for the presence of deep-living copepods in the 50-0 m samples, also contain eastern Mediterranean water. These species, however, appear too infrequently to be considered reliable indicators of waters of different origin.

\section{Conclusions}

The results of the cluster analysis and the inverse analysis reflect the geographical distribution of the species studied, separating the oceanic region from the neritic and nearcoastal region, during the appropriate season. The A and B clusters grouped the stations, based on the abundance and species composition, into near-coastal and neritic regions during the September, December, February and July sampling periods. The stations grouped in the $\mathrm{C}, \mathrm{D}$ and $\mathrm{E}$ clusters reflect the abundance and species composition in the oceanic region during early and mid-summer and the $\mathrm{F}$ cluster grouped stations with species composition characteristic for the oceanic region in December. 
Cluster analysis showed an obvious distinction between near-coastal/neritic stations with high copepod densities, and oceanic stations, with low densities and low species diversity. In winter this is due to a very low phytoplankton production, and in summer to zooplankton maxima deeper than $50 \mathrm{~m}$.

No sharp boundaries in copepod number, species composition, salinities and temperatures exist between the September, December and February sampling periods. The June and July sampling periods were different from the others.

Vertical mixing in February could be determined by: (a) presence of meso- and bathypelagic copepods in the 50-0 m samples and (b) uniform temperatures and salinities down to great depths. Local intermediate upwellings in summer, remaining below the thermocline, could be determined by: (i) the presence of meso- and bathypelagic copepods in the 50-0 m samples; (ii) a deep chlorophyll-rich layer, resulting from nutrient input from below; and (iii) high zooplankton biomass in the upper $100 \mathrm{~m}$ compared to the upper $50 \mathrm{~m}$.

Copepods with mainly herbivorous feeding strategies were highest in abundance but lowest in species diversity.

Paracalanus parvus replaced Clausocalanus spp. as the dominating species in the neritic region during the summer period.

The occasional appearance of indicator species of waters originating from the Atlantic and eastern Mediterranean is not enough to discuss the influence of these waters in the upper $50 \mathrm{~m}$.

\section{Acknowledgements}

I am greatly indebted to the Director and staff of the Laboratoire Arago at Banuyls-surMer for giving access to all facilities essential for carrying out this type of work. I should like to thank also the captain and crew of the Noroit, the Suroit and the Garcia del Cid, as well as French and Spanish colleagues for the sympathetic assistance in sampling; to Dr F. Lochet (Marseille) and Dr A. Cruzado (Blanes) for sending me hydrographical data. Special thanks are due to Dr C. Razouls and Dr S. Razouls for their personal interest, guidance and assistance, to Mme $\mathrm{N}$. Batailler and $\mathrm{Mr} \mathrm{N}$. Briand for their pleasant contribution to obtaining final results. I owe many thanks to Prof. Dr S. van der Spoel and Dr P. H. Schalk, Institute of Taxonomic Zoology, University of Amsterdam, for improvements and advice on the original manuscript; to Dr J. A. Kaandorp and Dr M. de Kluijver for their great help in cluster analysis. Thanks are also due to the anonymous referees for constructive criticism of this manuscript. This study was partly financially supported by grants from the Organization for the Advancement of Oceanography in the Netherlands (S.B.N.O), grant No. 91/BiOc/2, the 'Catherina van Tussenbroek' Fund (The Netherlands) and the French Ministry of Foreign Affairs.

\section{References}

Anraku, M. \& Omori, M. 1963 Preliminary survey of the relationship between the feeding habit and the structure of the mouth-parts of marine copepods. Limnology and Oceanography 8, 116-126.

Arashkevich, E. G. \& Timonin, A. G. 1970 The feeding of copepods in the tropical part of the pacific ocean. Doklady Akademii Nauk Soyuza Sovetskikh Sotsialisticheskikh Respublik 191, 935-938 (in Russian).

Bennet, J. L. \& Hopkins, T. L. 1989 Aspects of the ecology of the calanoid copepod genus Pleuromamma in the eastern Gulf of Mexico. Contributions to Marine Science 31, 119-136.

Boesch, D. F. 1977 Application of numerical classification in ecological investigations of waterpollution. Special Scientific Report No. 177 VIMS (EPA600Y3-7703), 1-114.

Brasseur, P. P. 1992 Initialization of 3D models of the western Mediterranean and of the Gulf of Lions: application of a variational method to the reconstruction of data fields. Commission of the European Communities Water Pollution Research Report 28, 39-50. 
Cahet, G., Fiala, M., Jacques, G. \& Panouse, M. 1972 Production primaire au niveau de la thermocline en zone néritique de Méditerranée Nord-Occidentale. Marine Biology 14, 32-40.

Corner, E. D. S. 1961 On the nutrition and metabolism of zooplankton. I. Preliminary observations on the feeding of the marine copepod. Calanus helgolandicus (Claus). Fournal of the Marine Biological Associaton of the United Kingdom 41, 5-16.

Cruzado A. \& Velasquez, Z. R. 1990 Nutrients and phytoplankton in the Gulf of Lions, northwestern Mediterranean. Continental Shelf Research 10, 931-942.

Daan, R., Gonzalez, S. R. \& Klein Breteler, W. C. M. 1988 Cannabalism in omnivorous calanoid copepods. Marine Ecology Progress Series 47, 45-54.

Davis, C. C. 1984 Planktonic copepoda (including Monstrilloida). In Marine Plankton Life Cycle Strategies (Steidinger, K. A. \& Walker, L. M., eds). CRC Press, Boca Raton, Florida, pp. 67-91.

Estrada, M., Vives, F. \& Alcaraz, M. 1985 Life and productivity of the open sea. In Western Mediterranean (Margalef, R., ed.). Pergamon Press, Oxford, pp. 148-197.

Field, J. G., Clarke, K. R. \& Warwick, R. M. 1982 A practical strategy for analysing multispecies distribution patterns. Marine Ecology Progress Series 8, 37-52.

Fieux, M. 1971 Observations hydroligiques hivernales dans le rech Lacaze-Duthiers (Golfe du Lion). Cahiers Océanographiques 8, 677-686.

Frost, B. \& Fleminger, A. 1986 A revision of the genus Clausacalanus (Copepoda: Calanoida) with remarks on distributional pattern diagnostic characters. Bulletin of the Scripps Institution of Oceanography 12, 1-235.

Furnestin, J. 1960 Hydrologie de la Méditerrannée occidentale (Golfe du Lion, Mer Catalane, Mer d'Alboran, Corse orientale) 14 juin-20 juillet 1957. Revue des Travaux de l'Institut des Pêches Martimes 24, 5-119.

Furnestin, J. \& Allain, C. 1962 Hydrologie de la Méditerrannée occidentale au nord du 42e parallele en automne 1958. (Campagne du navire «Président-Théordore-Tissiers $\gg$ du 27 septembre au 18 octobre 1958). Revue des Travaux de l'Institut des Pêches Maritimes 26, 133-161.

Furnestin, M. L. 1960 Zooplancton du Golfe du Lion et de la còte oriëntale de Corse. Revues et Travaux de l'Institut des Pêches Maritimes 24, 153-352.

Furnestin, M. L. 1979 Aspects of zoogeography of the Mediterranean plankton. In Zoogeography and Diversity of Plankton (van der Spoel, S. \& Pierrot-Bults, A. C., eds). Bunge Scientific, Utrecht, pp. 191-253.

Gaudy, R. 1963 Sur la présence à Marseille d'espèces planctioniques indicatrices d'eaux d'origine atlantique. Rapports et Commentaires Internationaux sur la Mer Méditerranéenne 17, 539-543.

Gaudy, R. 1970 Contribution à la connaissance du cycle biologique et de la physiologie des Copépodes du golfe de Marseille. Thèse de doctorat ès sciences naturelles, Université d'Aix Marseille, 294 pp.

Gaudy, R. 1971 Contribution à l'étude du cycle biologique des copépodes pélagiques du golfe de Marseille. I. l'Environnement physique et biotique et la composition de la population de copépodes. Téthys 3, 921-942.

Gaudy, R. 1972 Contribution à la connaissance du golfe de Marseille. II. Etude du cycle biologique de quelques espèces caractéristiques. Téthys $4,175-242$.

Gaudy, R. 1974 Feeding four species of Pelagic copepods under Experimental conditions. Marine Biology 25, 125-141.

Gaudy, R. 1985 Features and peculiarities of zooplankton communities from the Western Mediterranean. In Mediterranean Marine Ecosystems (Moraitou-Apostolopoulou, M. \& Kiortsís, V., eds). Plenum Press, New York, pp. 279-301.

Gowing, M. M. \& Garrison, D. L. 1991 Austral winter distributions of large tintinnid and large sarcodinid protozooplankton in the ice-edge zone of the Weddel/Scotia Seas. Fournal of Marine Systems 2, 131-141.

Harding, G. C. H. 1974 The food of deep-sea copepods. Fournal of the Marine Biological Association of the United Kingdom 54, 141-155.

Jacques, G., Razouls, C. \& Thiriot, A. 1969 Climat et hydrologie à Banyuls-sur-Mer (Golfe du Lion) 1965-1968. Vie Milieu 20, 279-316.

Jacques, G., Minas, H. J., Minas, M. \& Nival, P. 1973 Influence des conditions hivernales sur les productions phyto-et zooplanctoniques en Méditerranée Nord-Occidentale. II. Biomasse et production phytoplanctonique. Marine Biology 23, 251-265.

Jacques, G. \& Tréguer, P. 1986 Ecosystèmes Pélagiques Marins. Masson, Paris, 243 pp.

Kaandorp, J. A. 1986 Rocky substrate communities of the infralittoral fringe of the Boulonnais coast, NW France: a quantitative survey. Marine Biology 92, 255-265.

de Kluijver, M. J. 1989 Sublittoral hard substrate communities of the southern Delta area, SW Netherlands. Bijdragen tot de Dierkunde 59, 141-158.

Kouwenberg, J. H. M. 1993a Seasonal variation in copepod abundance in relation to other zooplankton groups in the northwestern Mediterranean. Bijdragen tot de Dierkunde 62, 215-226.

Kouwenberg, J. H. M. $1993 b$ Sex ratio of calanoid copepods in relation to population composition in the northwestern Mediterranean. Crustaceana 64, 201-299. 
Kouwenberg, J. \& Razouls, C. 1990 The incidence of environmental factors on the evolution of copepod populations in the 'Golfe du Lion' during the period 1986-88 in comparison with the period 1957-64. Bulletin de la Société Zoologique de France 115, 23-36.

Lampitt, R. S. 1978 Carnivorous feeding by a small marine copepod. Limnology and Oceanography 23, 1228-1231.

Longhurst, A. R. 1985 Relationship between diversity and the vertical structure of the upper ocean. Deep-Sea Research 32, 1535-1570.

Margalef, R. 1984 Le plancton de la Méditerranee. La Rechere 158, 1082-1094.

Mazza, J. 1966 Les copépods de la Méditerranée (bassin occidental). Commision Internationale pour l'Exploration scientifique de la Mer Méditerranée congres, Bucarest, $99 \mathrm{pp}$.

Mazza, J. 1967 Les copépods pélagiques en Méditerranée occidentale. Thèse de doctorat és sciences naturelles, Université d'Aix Marseille, $495 \mathrm{pp}$.

Millot, C. 1976 Specific features of the sea-shore circulation near Cap Leucate.Mémoires de la Société Royale des Sciences de Liège, Serie 6e 20, 227-245.

Millot, C. 1979 Wind induced upwellings in the Gulfe du Lions. Oceanologica Acta 2, 261-274.

Millot, C. 1981 La dynamique marine du plateau continental du Golfe du Lion en été. Thèse doctorat d'Etat es-sciences physiques, Université Paris.

Millot, C. 1987 Circulation in the Western Mediterranean Sea. Oceanologica Acta 10, 143-149.

Morel, A., Bricaud, A., André, J. M. \& Pelaez-Hudlet, J. 1990 Spatial temporal evolution of the Rhône plume as seen by CZCS imagery-consequences upon the primary production in the Gulf of Lions. Commission of the European Communities Water Pollution Research Report 20, 45-62.

Nassogne, A. 1970 Influence of food organisms on the development and culture of pelagic copepods. Helgoländer Wissenschäftliche Meeresuntersuchungen 20, 333-345.

Nihoul, J. C. J. \& Beckers, J. M. 1989 Preliminary results of a three-dimensional model of the western Mediterranean's general circulation. Commission of the European Communities. Water Pollution Research Report 13, 7-26.

Nihoul, J. C. J., Beckers, J. M., Brasseur, P., Deleersnijder, E., Djenidi, S., Lagasse, B., Robe, F. \& Smitz, J. 1990 Marine hydrodynamical and biogeochemical model: general 3D circulation model of the western Mediterranean Sea. Commission of the European Communities. Water Pollution Research Report 20,25-37.

Paffenhöfer, G. A. 1984 Food ingestion by the marine planktonic copepod Paracalanus in relation to abundance and size distribution of food. Marine Biology 80, 323-333.

Paffenhöfer, G. A. 1991 Some characteristics of abundant subtropical copepods in estuarine, shelf and oceanic waters. Proceedings of the Fourth International Conference on Copepoda; Bulletin of the Plankton Society of fapan Special Volume, pp. 201-216.

Paffenhöfer, G. A. \& Knowles, S. C. 1980 Omnivorousness in marine planktonic copepods. fournal of Plankton Research 2, 355-365.

Poulet, S. A. 1978 Comparison betwen five coexisting species of marine copepods feeding on naturally occurring particulate matter. Limnology and Oceanography 23, 1126-1143.

Poulet, S. A. \& Ouellet, G. 1982 The role of amino acids in the chemosensory swarming and feeding of marine copepods. Fournal of Plankton Research 4, 341-361.

Razouls, C. 1972 Estimation de la production secondaire (copépodes pélagiques) dans une province néritique Méditerranéenne (Golfe du Lion). Thèse de doctorat d'Etat ès sciences naturelles, Université Paris, 301 pp.

Razouls, C. 1973 Inventaire faunistique des Copépodes pélagiques de la région de Banyuls-sur-Mer (Golfe du Lion). Rapports et Procès-Verbaux des Réunions de la Commission Internationale pour l'Exploration Scientifique de la Mer Méditerranée 21, 465-469.

Razouls, C. \& Durand, J. 1991 Inventaire des copépodes planctoniques Méditerranéens. Vie Milieu 41, 73-77.

Razouls, C. \& Guinness, C. 1973 Variations saisonnières de la longueur et du volume chez Centropages typicus et Temora stylifera (Copepoda Calanoida) à Banyuls-sur-Mer (Golfe du Lion). Rapports et Procès-Verbaux des Réunions de la Commission Internationale pour l'Exploration Scientifique de la Mer Méditerranée 21, 479-481.

Razouls, C. \& Razouls, S. 1976 Dimensions, poids sec, valeur calorigique et courbes de croissance de deux populations naturelles de copépodes planctoniques en Méditerranée. Vie Milieu 26, 281-297.

Razouls, S. 1972 Variations annuelles du métabolisme respiratoire de deux copépodes pélagiques: Temora stylifera et Centropages typicus à Banyuls-sur-Mer (Golfe du Lion). Vie Milieu 22, 95-112.

Rose, M. 1933 Copépodes pelagiques. Faune de France 26, 374.

Saiz, E. \& Alcaraz, M. 1990 Pigment gut contents of copepods and deep phytoplankton maximum in the Western Mediterranean. Fournal of Plankton Research 12, 665-672.

Salat, J, Cruzado, A. \& Panouse, M. 1990 Contribution of the Rhone River water discharges to the dynamics of the Gulf of Lions in Autumn 1986. Rapports et Procés-Verbaux des Réunions de la Commission Internationale pour l'Exploration Scientifique de la Mer Méditerranée 32, 168.

Sewell, R. B. 1948 The free swimming planktonic copepoda. Geographical distribution. Scientific Reports of the fohn Murray Expedition 1933-34 8, 317-592. 
Sokal, R. R. \& Michener, C. D. 1958 A statistical method for evaluating systematic relationships. University of Kansas Science Bulletin 38, 1409-1438.

Thiriot, A. 1965 Campagne du navire océanographique 'Zenobe Gramme' (20 mars-2 avril 1964) Zooplancton de Golfe du Lion. Essai de justification de l'étude du zooplancton dans la détermination des différentes masses d'eau. Cahiers Océanographiques 17, 331-343.

Timonin, A. G. 1971 The structure of plankton communities of the Indian Ocean. Marine Biology 9, 281-289.

Tongeren, O. F. R. van 1987 Cluster analysis. In Data Analysis in Community and Landscape Ecology (Jongman, R. H. G., ter Braak, C. J. F. \& van Tongeren, O. F. R., eds). Pudoc, Wageningen, pp. 174-212.

Unesco. 1968 Smaller mesozooplankton. Report of Working Party No. 2. In Zooplankton Sampling (Fraser, J. H., ed.). UNESCO, Paris, pp. 153-159.

Vervoort, W. 1946 The bathypelagic Copepoda Calanoida of the Snellius Expedition I. Families Calanidae, Eucalanidae, Paracalanidae and Pseudocalanidae. Biological Results of the Snellius Expedition, XV. Temminckia 8, 1-181.

Vervoort, W. 1963 Pelagic Copepoda. Part I. Copepoda Calanoida of the families Calanidae up to and including Euchaetidae. Atlantide Report 7, 77-194.

Vervoort, W. 1965 Pelagic Copepoda. Part II. Copepoda Calanoida of the families Phaennidae up to and including Acartiidae, containing the description of a new species of Aetideidae. Atlantide Report 8, 9-216.

Vives, F. 1963 Sur les Copépodes néritiques (Calanoidae) de la Méditerranée occidentale (côtes de Castellon, Espagne). Rapports et Procès-Verbaux des Réunions de la Commission Internationale pour l'Exploration Scientifique de la Mer Méditerranée 17, 547-554.

Wiadnyana, N. N. \& Rassoulzadegan, F. 1989 Selective feeding of Acartia clausi and Centropages typicus on microzooplankton. Marine Ecology Progress Series 53, 37-45.

Wickstead, J. H. 1959 A predatory copepod. Fournal of Animal Ecology 28, 69-72.

Wickstead, J. H. 1962 Food and feeding in pelagic copepods. Proceedings of the Zoological Society of London $139,545-555$. 